\title{
Human Mannose-binding Protein Functions as an Opsonin for Influenza A Viruses
}

\author{
Kevan L. Hartshorn, * Kedarnath Sastry, * Mitchell R. White, * E. Margot Anders, ${ }^{5}$ Michael Super, ${ }^{*}$ \\ R. Alan Ezekowitz, ${ }^{*}$ and Alfred I. Tauber* \\ * Departments of Medicine and Pathology, Boston University School of Medicine and the Department of Medicine, Boston City Hospital, \\ Boston, Massachusetts 02118; Divisions of ${ }^{\ddagger}$ Hematology/Oncology and Infectious Diseases, Department of Pediatrics, Children’s \\ Hospital and Dana Farber Cancer Institute, Harvard Medical School, Boston, Massachusetts 02115; \\ and ${ }^{\S}$ Department of Microbiology, University of Melbourne, Victoria, Australia
}

\begin{abstract}
Influenza A viruses (IAVs) cause substantial morbidity and mortality in yearly epidemics, which result from the ability of the virus to alter the antigenicity of its envelope proteins. Despite the rapid replication of this virus and its ability to infect a wide variety of cell types, viremia is rare and the infection is generally limited to the upper respiratory tract. The preimmune host defense response against IAV is generally, therefore, successful. We have previously provided (and summarized) evidence that neutrophils contribute to defense against IAV, although neutrophil dysfunction and local tissue damage may be less salutory byproducts of this response. Here we provide evidence that the serum lectin mannose-binding protein directly inhibits hemagglutinin activity and infectivity of several strains of IAV. In addition mannose-binding protein acts as an opsonin, enhancing neutrophil reactivity against IAV. Opsonization of IAV by mannose-binding protein also protects the neutrophil from IAV-induced dysfunction. These effects are observed with physiologically relevant concentrations of mannose-binding protein. Two different allelic forms of recombinant mannose-binding protein are found to have similar effects. We believe, on the basis of these data, that mannose-binding protein alone and in conjunction with phagocytic cells is an important constituent of natural immunity (i.e., preimmune defense) against IAV. (J. Clin. Invest. 1993.91:1414-1420.) Key words: neutrophils • hemagglutination • recombinant proteins • mannose-binding protein $\bullet$ influenza $A$ virus
\end{abstract}

\section{Introduction}

The product of influenza A virus (IAV) ${ }^{1}$ hemagglutinin (HA) genes is expressed on the surface of infected cells and evokes specific and long-lived humoral and cell-mediated immune re-

A preliminary report of some of the data presented in this paper has been published in abstract form (1991. J. Cell Biol. 115:361a.)

Address correspondence to Kevan L. Hartshorn, Department of Medicine, Boston University School of Medicine, 80 East Concord St., Boston, MA 02118-2394.

Received for publication 13 August 1992 and in revised form 12 November 1992.

1. Abbreviations used in this paper: HA, hemagglutinin; HAU, hemagglutinin units; IAV, influenza A virus; MBP, mannose-binding protein; PFU, plaque-forming units; rMBP, recombinant MBP.

J. Clin. Invest.

(C) The American Society for Clinical Investigation, Inc.

0021-9738/93/04/1414/07 \$2.00

Volume 91, April 1993, 1414-1420 sponses (1). However, frequent mutations occur in HA genes such that antigenic determinants of the virus are altered, rendering previously immune individuals susceptible to repeat infection (2). These changes result in frequent epidemics and, occasionally, pandemics of influenza. Although considerable morbidity and mortality may be associated with these outbreaks, there is heterogeneity in the clinical outcome for different individuals infected with the same viral strain (3). For half a century it has been recognized that serum factors can inhibit influenza hemagglutination (4). Recently, it has been established that one class of serum HA inhibitors, the "beta" inhibitors, are mannose-binding lectins $(4,5)$. Several strains of IAV that have been selected on the basis of resistance to growth inhibition by beta inhibitors have been characterized $(4,5)$. In each case a specific mutation has been found in the resistant strain (as compared with the parent, sensitive, strain), that leads to loss of a specific glycosylation site. For two of the strains, the parent virus is known to have at this site a high mannose glycan attachment that lies in close proximity to the cell attachment site of the HA. These findings suggest that beta inhibitors of IAV act by binding to these high mannose structures, thus masking the cell attachment domain of the HA.

Two candidate serum lectins that may constitute beta inhibitors are mannose-binding protein (MBP) and conglutinin (57). MBP and conglutinin are members of a family of mammalian serum lectins that have in common $\mathrm{a} \mathrm{Ca}^{2+}$-dependent lectin-binding domain at the $\mathrm{COOH}$ terminus and a collagenous domain followed by a short area of disulfide bonds at the $\mathrm{NH}_{2}$ terminus (6). Both are present as multimeric structures in serum. Structurally both resemble $\mathrm{Clq}$ and are able to bind to $\mathrm{Clq}$ receptors through their collagen domain $(6,7)$.

This study has focused on the interaction of recombinant MBPs with several strains of IAV. MBPs have been characterized in the serum of mice, rats, rabbits, and humans $(6,7)$. The physiological role for these proteins appears to be in first line host defense and they may be considered as pattern-recognition molecules that function as ante-antibodies (8). MBPs are acute-phase reactants $(9,10)$ that recognize a wide variety of disparate oligosaccharides that are present on the cell walls of certain Gram-negative bacteria (11), fungal pathogens (12), and the envelope glycoprotein of human immunodeficiency virus (13). There are at least two allelic variants of MBP. In the vast majority of individuals there is one aberration in the collagen region at the eighth repeat as Gly-Gln-Gly is present rather than Gly-X-Y-Gly. In 5-7\% of the population Asp replaces Gly at the fifth collagen repeat, in addition to the irregularity observed more commonly (14). Homozygosity for this latter phenotype appears to segregate with low serum MBP levels, which in turn have been associated with the phenotype of recurrent infections $(14,15)$. However, in recent studies both allelic 
forms of MBP have been shown to have similar functional properties in vitro. One important difference is that the recombinant MBP containing the Gly to Asp mutation at the fifth collagen repeat was not able to fix complement via the classical pathway (14). In this paper we assess the interaction of both forms of MBP with various influenza viral strains selected for known differences in HA glycosylation.

MBP-ligand complexes would be expected to encounter circulating cells, in particular neutrophils, which have been shown to ingest bacteria opsonized with MBP (11). Neutrophils alone may play a role in the preimmune host defense against influenza $(16,17)$. We and others have characterized the interaction of human neutrophils with unopsonized IAV and found evidence that these cells are activated by IAV. In the absence of antibody, neutrophils are stimulated by cell-free virus to generate a pertussis toxin-insensitive respiratory burst response, characterized by hydrogen peroxide $\left(\mathrm{H}_{2} \mathrm{O}_{2}\right)$, but no superoxide $\left(\mathrm{O}_{2}^{-}\right)$production $(18,19)$. Neutrophils are also reported to specifically adhere to IAV-infected epithelial monolayers without mediation of antibody (20). After exposure to influenza viruses in vitro and in vivo, however, neutrophils and monocytes exhibit depressed responsiveness to various stimuli and depressed microbicidal activity against bacteria $(21,22)$. In this report we demonstrate that both forms of recombinant MBP inhibit IAV HA activity and act as opsonins, enhancing neutrophil responsiveness to the virus.

\section{Methods}

Reagents. FMLP, cytochalasin B, horseradish peroxidase type II, scopoletin, SOD, cytochrome $c$, neuraminidase type $\mathrm{X}$ (protease activity $<0.002 \mathrm{U} / \mathrm{mg}$ protein ), ficol, dextran, sodium citrate, citric acid, and nitroblue tetrazolium were purchased from Sigma Chemical Co. (St. Louis, MO) and Hypaque was obtained from Winthrop Pharmaceuticals (Des Plaines, IL). Fura-2 and bis-(1,3-diethyl-barbituric acid) trimethoxynol (bisoxynol) were purchased from Molecular Probes, Inc. (Eugene, OR), organic solvents from Fisher Scientific (Fairlawn, NJ), and Dulbecco's phosphate-buffered saline with $\mathrm{Ca}^{2+}$ or $\mathrm{Mg}^{2+}\left(\mathrm{PBS}^{2+}\right)$ or without $\mathrm{Ca}^{2+}$ or $\mathrm{Mg}^{2+}$ from Flow Laboratories (McLean, VA). Pertussis toxin was purchased from List Biological Laboratories, Inc. (Campbell, CA).

$M B P$ preparation. Recombinant $\mathrm{MBP}_{\mathrm{G}}\left(\mathrm{rMBP}_{\mathrm{G}}\right)$ and $\mathrm{rMBP} \mathrm{P}_{\mathrm{D}}$ were prepared from cDNAs differing only at base pair 230 . These cDNAs were subcloned in a eukaryotic expression vector transfected into murine $\mathrm{Sp} 2$ cells and MBPs were purified from the supernatants by calcium-dependent binding to mannan-Sepharose and EDTA elution or by binding to an affinity matrix of anti-MBP monoclonal antibody coupled to Affigel (Bio-Rad Laboratories, Richmond, CA) as previously described (14). MBPs were dialyzed in PBS and stored at $-70^{\circ} \mathrm{C}$ in aliquots. The specific activities were measured by comparison with a standard preparation using mannan-coated ELISA plates as described (14).

Virus preparation. Virus stocks were grown in the chorioallantoic fluid of 10-d-old embryonated hen's eggs and purified on a discontinuous sucrose density gradient as previously described (21). Virus stock was suspended in Dulbecco's modified PBS, aliquoted, and stored at $-70^{\circ} \mathrm{C}$ until used. Potency of each virus stock was measured by hemagglutination assay, and titers of 1:8,000-32,000 (as indicated) hemagglutination units (HAU) were measured after samples were thawed from frozen storage at $-70^{\circ} \mathrm{C}$. The $\mathrm{H}_{3} \mathrm{~N}_{2}$ A Texas 77 (Texas 77) and $\mathrm{H}_{1} \mathrm{~N}_{1} \mathrm{~A} / \mathrm{PR} / 8 / 34$ (PR-8) strains of IAV were gracious gifts of Dr. Jon Abramson (Bowman-Gray School of Medicine, Winston-Salem, NC). The $\mathrm{H}_{3} \mathrm{~N}_{1} \mathrm{~A} /$ Memphis $71_{\mathrm{H}}-\mathrm{Bel}_{\mathrm{N}}$ virus was obtained originally from Dr. W.G. Laver (John Curtin School of Medical Research,
Canberra, Australia) and the beta-inhibitor resistant mutant $\left(\mathrm{Mem} 71_{\mathrm{H}^{-}}-\mathrm{Bel}_{\mathrm{N}} / \mathrm{BS}\right.$ ) was developed by Dr. E. Margot Anders (University of Melbourne, Parkville, Victoria, Australia). The $\mathrm{H}_{3} \mathrm{~N}_{2}$ /A/Bangkok/1/79 (Bankok 79) strain was a gift of Dr. Robert Webster (St. Jude's Hospital, Memphis, TN). HA titers were determined by titration of virus samples in PBS followed by addition of thoroughly washed human type $\mathrm{O}$ red blood cells.

Incubation of MBPs with concentrated IAV stocks was carried out for $0.5 \mathrm{~h}$ at $37^{\circ} \mathrm{C}$ in $\mathrm{PBS}$ with $1 \mathrm{mM} \mathrm{Ca}^{2+}$ and $\mathrm{Mg}^{2+}$, except in certain experiments where $2 \mathrm{mM}$ EGTA or $10 \mathrm{mg} / \mathrm{ml}$ mannan (Sigma Chemical Co.) were added, as indicated. For experiments with neutrophils, aliquots of virus or MBP-treated virus were then added to cell suspension at a 1:40 vol/ $\mathrm{vol}$ ratio. In describing these experiments, the final concentration of MBP in the neutrophil suspension is given.

Virus plaque formation was assessed on Madin-Darby canine kidney cells: duplicate confluent monolayers in six-well plates were exposed to virus preparations with or without MBP in 10-fold dilutions in serum-free CRCM-30 medium (Sigma Chemical Co.) for $1 \mathrm{~h}$ at $37^{\circ} \mathrm{C}$, followed by washing twice in PBS. The monolayers were then overlaid with CRCM-30 media with $0.1 \%$ BSA, $0.4 \%$ agarose, $10 \mu \mathrm{g} / \mathrm{ml}$ trypsin, and $10 \mu \mathrm{g} / \mathrm{ml}$ DEAE-Dextran. The agarose solution was warmed until melting and allowed to cool to the touch, and then mixed with the other ingredients and layered over the cells before solidification. The monolayers were then kept at $37^{\circ} \mathrm{C}$ in a $5 \% \mathrm{CO}_{2}$ incubator for $72 \mathrm{~h}$, followed by removal of the agarose overlay. After staining with crystal violet, the plaques were counted by direct inspection and titers of plaque-forming units (PFU) $/ \mathrm{ml}$ calculated. Values given are mean PFU $/ \mathrm{ml}$ for two wells. MDCK cells were obtained from the American Type Culture Collection (Rockville, MD).

Neutrophils from healthy volunteer donors were isolated to $>95 \%$ purity as previously described using dextran precipitation, followed by a Ficoll-Hypaque gradient separation for removal of mononuclear cells and hypotonic lysis to eliminate contaminating erythrocytes (21). Cell viability was $>98 \%$ as determined by trypan blue staining, and cells were used within $5 \mathrm{~h}$ of isolation.

Measurement of neutrophil activation. $\mathrm{H}_{2} \mathrm{O}_{2}$ production was measured by the oxidation of scopoletin, and $\mathrm{O}_{2}^{-}$was assessed by the continuous monitoring of the SOD-inhibitable reduction of cytochrome $c$ as previously detailed (18). Cell membrane potential was measured using the fluorescent probe bisoxynol as previously detailed (18). Neutrophil deactivation was assessed by first incubating cells with IAV (either unopsonized or opsonized with MBP) for various periods of time followed by measurement of $\mathrm{O}_{2}^{-}$production in response to FMLP.

In some of the assays of $\mathrm{H}_{2} \mathrm{O}_{2}$ or $\mathrm{O}_{2}^{-}$production, mannan alone or MBP treated with mannan were added before stimulation of the cells with IAV or FMLP. It was, however, observed that mannan alone, at quantities sufficient to inhibit the effects of MBP on viral HA activity, inhibited respiratory burst responses to both stimuli. Final concentrations of 250 or $500 \mu \mathrm{g} / \mathrm{ml}$ of mannan reduced both $\mathrm{H}_{2} \mathrm{O}_{2}$ and $\mathrm{O}_{2}^{-}$ responses by $\geq 30 \%(n=3)$. Concentrations of mannan $\geq 500 \mu \mathrm{g} / \mathrm{ml}$ also inhibited the measured $\mathrm{O}_{2}^{-}$produced by xanthine oxidase in a dose-related manner. The inhibitory effects of mannan on neutrophil respiratory burst responses was, therefore, at least in part attributable to direct interference with $\mathrm{O}_{2}^{-}$detection. As detailed below, mannan did not interfere with neutrophil membrane depolarization responses, so this assay was used to assess the ability of mannan to alter the effects of MBP on neutrophil activation responses to IAV.

\section{Results}

\section{Effect of MBP on IAV infectivity and hemagglutination titers}

The IAV strains used in these experiments were selected to assess the role of high mannose oligosaccharide attachments to the viral HA in mediating MBP-IAV interactions. In Table I 
Table I. Inhibition of IAV Hemagglutination Activity and Enhancement of IAV-induced Neutrophil $\mathrm{H}_{2} \mathrm{O}_{2}$ Production by Various IAV Strains Opsonized with $r M B P_{G}$

\begin{tabular}{clc}
\hline & HA Inhibition & \\
\cline { 2 - 2 } IAV strain & $\mathrm{rMBP}_{\mathrm{G}}$ concentration & $\mathrm{H}_{2} \mathrm{O}_{2}$ Enhancement \\
\hline
\end{tabular}

$\begin{array}{lcc} & & \text { nmol/min per } 4 \times 10^{6} \text { cells } \\ \text { Mem71 } & & \\ \mathrm{H}^{-}-\mathrm{Bel}_{\mathrm{N}}(\mathrm{H} 3 \mathrm{~N} 1)^{*} & 368 \mathrm{ng} & 0.06 \pm 0.02^{\ddagger} \\ \text { Texas } 77(\mathrm{H} 3 \mathrm{~N} 2)^{*} & 224 \mathrm{ng} & 0.13 \pm 0.03^{\ddagger} \\ \text { Bankok } 79(\mathrm{H} 3 \mathrm{~N} 2)^{*} & 112 \mathrm{ng} & 0.06 \pm 0.01^{\ddagger} \\ {\text { Mem } 71_{\mathrm{H}^{-}}-\mathrm{Bel}}_{\mathrm{N}} / \mathrm{BS} & & \\ (\mathrm{H} 3 \mathrm{~N} 1)^{8} & 18 \mu \mathrm{g} & -0.01 \pm 0.01 \\ \text { PR-8 }(\mathrm{H} 1 \mathrm{~N} 1)^{8} & >35 \mu \mathrm{g} & -0.01 \pm 0.02\end{array}$

HA inhibition was performed by taking 1-2 HAU of the IAV strains and determining the concentration of $\mathrm{rMBP}_{\mathrm{G}}$ required to fully inhibit red cell hemagglutination by this amount of virus. Final volume of the virus, MBP, and red cell mixture was $100 \mu$ l. Results represent mean of two or three determinations. $\mathrm{H}_{2} \mathrm{O}_{2}$ enhancement refers to the ability of $\mathrm{rMBP}_{\mathrm{G}}$ to enhance the $\mathrm{H}_{2} \mathrm{O}_{2}$ response of human neutrophils (measured using the scopoletin fluorescence assay) elicited by the IAV strains. The rates of $\mathrm{H}_{2} \mathrm{O}_{2}$ production by the unopsonized viruses were, respectively, $0.08,0.07,0.05,0.08$, and $0.05 \mathrm{nmol} / \mathrm{min}$ per $4 \times 10^{6}$ cells for Mem71 $1_{\mathrm{H}^{-}}-\mathrm{Bel}_{\mathrm{N}}$, Texas 77, Bankok 79, Mem $71_{\mathrm{H}^{-}}$ $\mathrm{Bel}_{\mathrm{N}} / \mathrm{BS}$, and PR-8. The values given in the table represent mean \pm SEM difference in response of neutrophils to the various IAV strains opsonized with $\mathrm{rMBP}_{\mathrm{G}}$ compared with the respective control responses. For these experiments concentrated stocks of the viruses $(16,000-32,000 \mathrm{HAU} / \mathrm{ml})$ were preincubated for $30 \mathrm{~min}$ at $37^{\circ} \mathrm{C}$ with $\mathrm{rMBP}_{\mathrm{G}}$ or control buffer, followed by addition of aliquots of these preparations to neutrophil suspensions for $\mathrm{H}_{2} \mathrm{O}_{2}$ assay. The final concentration of $\mathrm{rMBP}_{\mathrm{G}}$ in the neutrophil suspension was $0.88 \mu \mathrm{g} / \mathrm{ml}$. Use of fivefold higher concentrations of $\mathrm{rMBP}_{\mathrm{G}}$ did not alter the negative results obtained with $\mathrm{Mem} 71_{\mathrm{H}}-\mathrm{Bel}_{\mathrm{N}} / \mathrm{BS}$ or PR-8.

* IAV strains with high mannose carbohydrate attachment on HA residue 165 .

${ }^{8}$ IAV strains without high mannose carbohydrate attachment on HA residue 165.

${ }^{\ddagger} P<0.05$ comparing response to unopsonized and $\mathrm{rMBP}_{\mathrm{G}}$-opsonized IAV. the IAV strains used are grouped according to whether they have a high mannose carbohydrate attachment at residue 165 of the HA. This attachment, when present, is adjacent to the sialic acid-binding pocket of the globular head of the HA. Mem $71_{\mathrm{H}}-\mathrm{Bel}_{\mathrm{N}} / \mathrm{BS}$, which lacks this attachment, is a mutant version of $\mathrm{Mem} 71_{\mathrm{H}^{-}}-\mathrm{Bel}_{\mathrm{N}}$, selected out by virtue of resistance to bovine serum beta inhibitors (4). PR-8 is an H1N1 strain of IAV that lacks high mannose oligosaccharide attachments on its HA (23) and specifically has no carbohydrate attachment near the sialic acid-binding site (24).

We carried out detailed studies of the effects of $\mathrm{rMBP}_{\mathrm{G}}$ on viral HA titers. As shown in Table I, the HA activity of 1-2 HAU of those viral strains with high mannose attachment adjacent to the cell attachment site of the HA (i.e., Texas 77, Mem $71_{\mathrm{H}}-\mathrm{Bel}_{\mathrm{N}}$, and Bankok 79) was inhibited by preincubation with nanogram concentrations of $\mathrm{rMBP}_{\mathrm{G}}$ whereas that of the strains without such carbohydrate attachments (i.e., PR-8 and $\mathrm{Mem} 71_{\mathrm{H}}-\mathrm{Bel}_{\mathrm{N}} / \mathrm{BS}$ ) were either not inhibited or inhibited at substantially greater $\mathrm{rMBP}_{\mathrm{G}}$ concentrations. For the Mem $71_{\mathrm{H}}-\mathrm{Bel}_{\mathrm{N}} / \mathrm{BS}, \sim 50$-fold more $\mathrm{MBP}$ was required to inhibit HA activity than for the parent virus. As depicted in Fig. 1 , when preincubated with a highly concentrated stock of

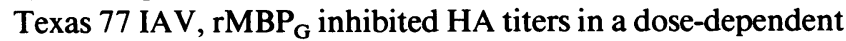
manner, and this effect was abrogated by addition of mannan (or EGTA) to $\mathrm{rMBP}_{\mathrm{G}}$ before addition of the virus.

To examine whether $\mathrm{rMBP}_{\mathrm{G}}$ could inhibit viral infectivity we also tested the effects of preincubation with $\mathrm{rMBP}_{\mathrm{G}}$ on plaque titers of IAV. Aliquots of highly concentrated IAV were preincubated with the lectin exactly as described in fig. 1. For the Texas 77 strain, preincubation of a preparation containing $2 \times 10^{9} \mathrm{PFU} / \mathrm{ml}$ with $70 \mu \mathrm{g} / \mathrm{ml} \mathrm{rMBP} \mathrm{G}_{\mathrm{G}}$ caused a one-log reduction in PFU titer (i.e., to a mean PFU titer of $1.5 \times 10^{8} ; n$ $=2$ experiments). When a starting PFU titer of $2 \times 10^{8}$ was used, $35 \mu \mathrm{g} / \mathrm{ml}$ of $\mathrm{rMBP}_{\mathrm{G}}$ caused a two-log reduction. A log reduction of PFU titer of concentrated $\mathrm{Mem} 71_{\mathrm{H}}-\mathrm{Bel}_{\mathrm{N}}$ resulted from preincubation with $35 \mu \mathrm{g} / \mathrm{ml} \mathrm{rMBP}_{\mathrm{G}}$ whereas no, or minimal, inhibition of PFU titers of the glycosylation mutant were seen in three experiments (data not shown). These results show that MBP can inhibit infectivity of H3 IAV strains, probably through binding to high mannose carbohydrate attachments on the viral HA.

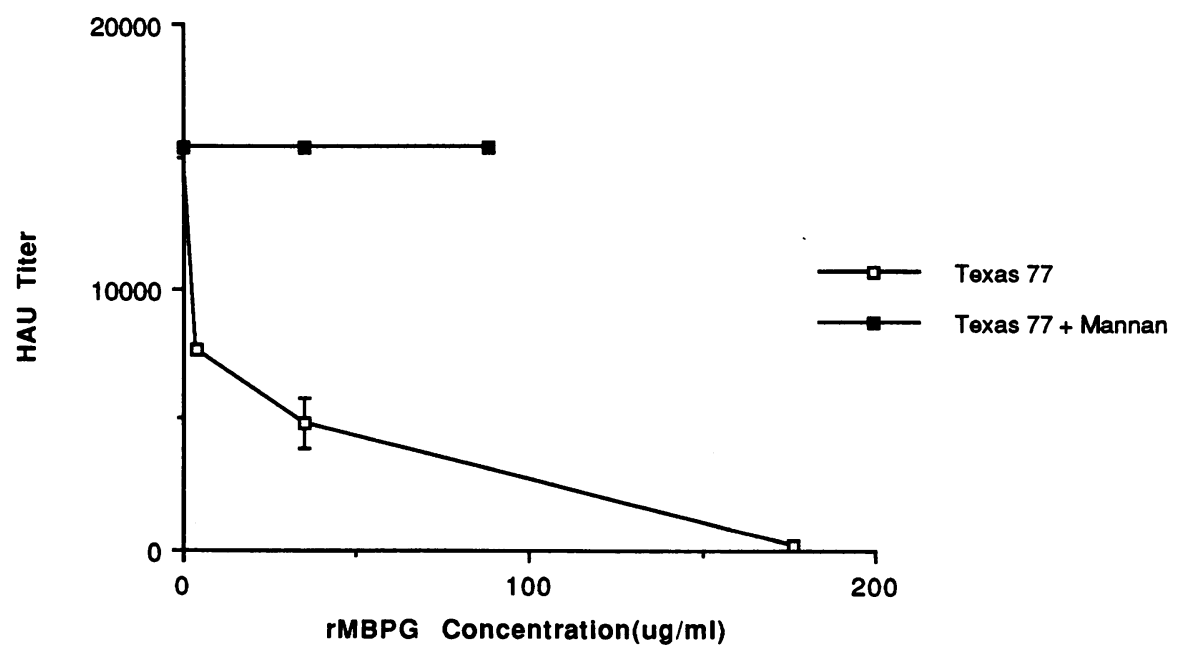

Figure 1. Effect of preincubation of Texas 77 IAV with rMBPG on viral HAU titers. Concentrated Texas 77 IAV was preincubated with various concentrations of rMBPG for $0.5 \mathrm{~h}$ at $37^{\circ} \mathrm{C}$, followed by assessment of viral HAU titers by titration of samples on human type $\mathrm{O}$ red blood cells. Results represent mean \pm SEM of four experiments. HAU titers were significantly reduced $(P<0.05)$ by all concentrations of MBP. In three experiments MBP was preincubated with mannan $(10 \mathrm{mg} / \mathrm{ml})$ before addition of IAV, which abrogated the effect of MBP. Where error bars are not shown identical results were obtained on repeated experiments. Chelation of $\mathrm{Ca}^{2+}$ with $5 \mathrm{mM}$ EGTA during incubation of virus with $\mathrm{MBP}$ also substantially inhibited the effect of MBP (data not shown). 


\section{Enhancement of IAV-induced neutrophil activation by preincubation with $M B P$}

Respiratory burst responses. As shown in Table I, when neutrophils were exposed to Texas 77, Bangkok 79, or $\mathrm{Mem} 71_{\mathrm{H}}-\mathrm{Bel}_{\mathrm{N}}$ strains of IAV opsonized with $0.88 \mu \mathrm{g} / \mathrm{ml}$ of $\mathrm{rMBP}_{\mathrm{G}}$, significantly enhanced $\mathrm{H}_{2} \mathrm{O}_{2}$ production was stimulated compared with that elicited by the unopsonized viruses. $\mathrm{H}_{2} \mathrm{O}_{2}$ enhancement was not seen when the PR-8 or Mem $71_{\mathrm{H}}-\mathrm{Bel}_{\mathrm{N}} / \mathrm{BS}$ strains were opsonized with $\mathrm{rMBP}_{\mathrm{G}}$. These results, therefore, parallel the HA inhibition results in that strains lacking high mannose glycosylation on the HA globular head are unaffected. The effects of preincubating MBP with mannan (to block lectin activity) could not be tested in this assay because of direct interference of mannan on respiratory burst assays ( see above).

Fig. $2 \mathrm{~A}$ depicts the dose-response relationship for $\mathrm{H}_{2} \mathrm{O}_{2}$ enhancement by $\mathrm{rMBP}_{\mathrm{G}}$ for the Texas 77 and PR-8 strains. Preincubation of Texas $77 \mathrm{IAV}$ with $\mathrm{rMBP}_{\mathrm{G}}$ caused a concentration-related enhancement of neutrophil $\mathrm{H}_{2} \mathrm{O}_{2}$ production in response to the virus. This enhancement was most consistent with 0.88 and $4.4 \mu \mathrm{g} / \mathrm{ml}$ of $\mathrm{rMBP}_{\mathrm{G}}$. Note again that $\mathrm{rMBP}_{\mathrm{G}}$ did not alter $\mathrm{H}_{2} \mathrm{O}_{2}$ responses to the PR-8 strain of IAV (Fig. 2). A representative tracing of scopoletin fluorescence decrease (indicative of $\mathrm{H}_{2} \mathrm{O}_{2}$ production) in response to MBP-opsonized IAV is given in Fig. $2 B$. Note that preincubation of the virus with the lectin was necessary to achieve enhancement. When MBP alone was added to neutrophils, followed by addition of IAV, no significant enhancement was seen (Fig. $2 B$ ). Preincubation of neutrophils with MBP alone similarly did not enhance $\mathrm{H}_{2} \mathrm{O}_{2}$ responses to FMLP (data not shown), indicating that the lectin did not have a general priming effect on neutro- phil responses. Also note that neither $\mathrm{H}_{2} \mathrm{O}_{2}$ nor $\mathrm{O}_{2}^{-}$production was induced by MBP alone (Fig. $2 B$ and data not shown).

Neutrophil membrane depolarization. IA V-induces neutrophil membrane depolarization in a time course similar to the induction of $\mathrm{H}_{2} \mathrm{O}_{2}$ production $(18,19)$. Preincubation of IAV with MBP significantly enhanced this response. Texas 77 IAV opsonized with $2.2 \mu \mathrm{g} / \mathrm{ml} \mathrm{rMBP}{ }_{\mathrm{G}}$ increased the rate of neutrophil membrane depolarization (as measured by changes in bisoxynol fluorescence) from $7 \pm 1$ for virus alone to $15 \pm 3$ for MBP-opsonized virus. These results are mean \pm SEM change in arbitrary fluorescence units $(n=4 ; P<0.03$ for IAV alone vs. MBP-opsonized IAV). When MBP was preincubated with mannan $(10 \mathrm{mg} / \mathrm{ml})$ before addition of virus, the enhancing effect of MBP was lost: mean \pm SEM depolarization rate of $7 \pm 2$ for IAV incubated with MBP and mannan. In contrast to its effects on respiratory burst assays, mannan alone (at the same concentration) did not significantly alter the membrane depolarization response to IAV (mean \pm SEM depolarization rate was $7 \pm 2$ for mannan plus IAV) nor did it alter the depolarization response to FMLP (data not shown).

\section{$M B P$ protects neutrophils from the deactivating effects of IAV}

In addition to causing neutrophil activation, influenza $\mathrm{A}$ viruses also suppress respiratory burst and other responses of the infected neutrophil to subsequent stimulation by a wide range of agonists $(21,22)$. This dysfunction (termed deactivation) can be shown by first incubating neutrophils with IAV and then measuring $\mathrm{O}_{2}^{-}$responses to FMLP. As shown in Table II, a

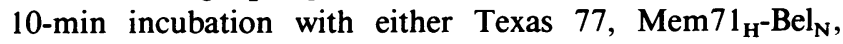

\section{A}

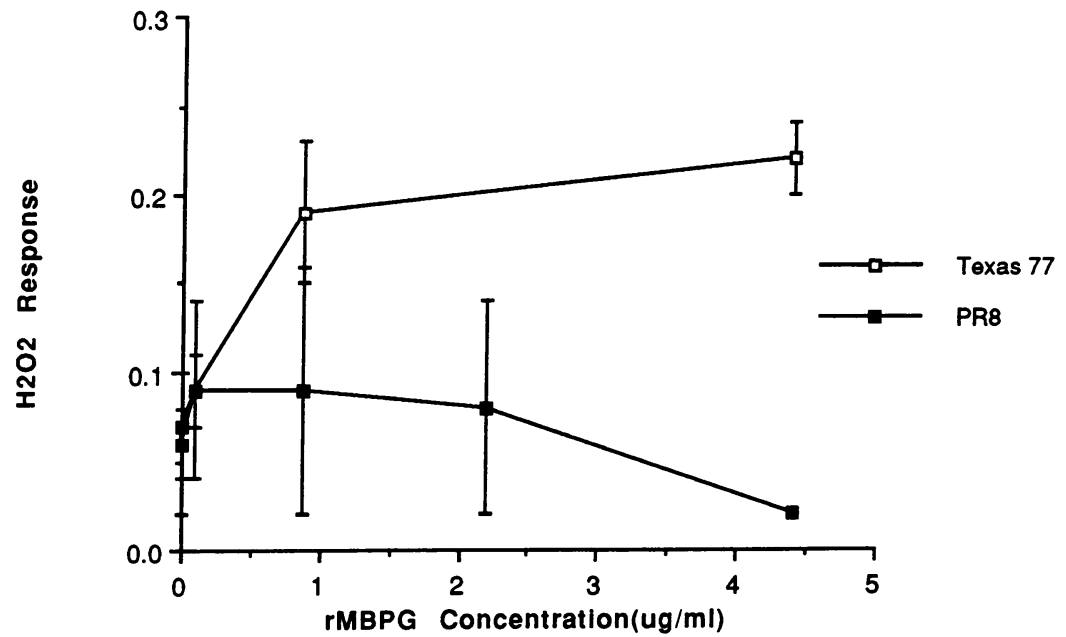

B

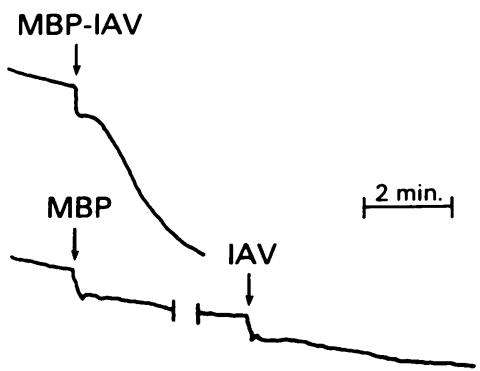

Figure 2. (A) Effects of opsonization of Texas 77 or PR-8 IAV with $\mathrm{rMBP}_{\mathrm{G}}$ on human neutrophil $\mathrm{H}_{2} \mathrm{O}_{2}$ production induced by these viruses. Aliquots of Texas 77 or PR-8 IAV (final concentrations of 384 and $320 \mathrm{HAU} / \mathrm{ml}$, respectively) were added to a stirred suspension of human neutrophils $\left(4 \times 10^{6}\right.$ cells in $\left.2 \mathrm{ml}\right)$, and $\mathrm{H}_{2} \mathrm{O}_{2}$ production was measured by decreases in scopoletin fluorescence. The viruses were either unopsonized or opsonized with $\mathrm{rMBP}_{\mathrm{G}}$ (final concentrations of MBP $0.088,0.88$, and $4.4 \mu \mathrm{g} / \mathrm{ml}$ ). Results represent mean \pm SEM of four experiments. For Texas $77 \mathrm{IAV}, \mathrm{H}_{2} \mathrm{O}_{2}$, production rates (in $\mathrm{nmol} / \mathrm{min}$ per $4 \times 10^{6}$ cells) were significantly elevated by samples opsonized with either 0.88 or $4.4 \mu \mathrm{g} / \mathrm{ml}$ MBP compared with those stimulated by IAV alone $(P<0.025)$. Responses to PR-8 were not significantly affected by MBP. ( $B$ ) Representative tracings of neutrophil $\mathrm{H}_{2} \mathrm{O}_{2}$ production (as indicated by a decline in fluorescence of scopoletin) in response to Texas 77 IAV that had been preincubated for $30 \mathrm{~min}$ with $\mathrm{rMBP}_{\mathrm{G}}(\mathrm{MBP}-\mathrm{IAV})$ as compared with the response to the same amounts of $\mathrm{rMBP}_{\mathrm{G}}$ alone followed by IAV alone. The final concentrations of $\mathrm{rMBP}_{\mathrm{G}}$ and $\mathrm{IAV}$ in the cell suspension were, respectively, $2.2 \mu \mathrm{g} / \mathrm{ml}$ and $384 \mathrm{HAU} / \mathrm{ml}$. Two or more additional experiments showed similar results. 
Table II. Effect of $r M B P_{G}$ on IAV-induced Neutrophil Deactivation

\begin{tabular}{|c|c|c|c|c|c|}
\hline \multirow[b]{2}{*}{ IAV strain } & \multicolumn{5}{|c|}{$\mathrm{rMBP}_{\mathrm{G}}$ concentrations } \\
\hline & 0 & 0.88 & 1.76 & 4.4 & 6.6 \\
\hline & \multicolumn{5}{|c|}{$\mu g / m l$} \\
\hline Texas 77 & $71 \pm 5^{*}$ & $71 \pm 5$ & ND & $83 \pm 4^{\ddagger}$ & $89 \pm 2^{\ddagger}$ \\
\hline $\operatorname{Mem} 71_{\mathrm{H}^{-}}-\mathrm{Bel}_{\mathrm{N}}$ & $76 \pm 3^{*}$ & ND & $81 \pm 3^{\ddagger}$ & $87 \pm 4^{\ddagger}$ & ND \\
\hline $\operatorname{Mem} 71_{\mathrm{H}}-\mathrm{Bel}_{\mathrm{N}} / \mathrm{BS}$ & $80 \pm 4^{*}$ & ND & $79 \pm 7$ & $80 \pm 9$ & ND \\
\hline PR-8 & $80 \pm 5^{*}$ & ND & $82 \pm 2$ & $78 \pm 6$ & ND \\
\hline
\end{tabular}

Various virus strains were preincubated with control buffer or various concentrations of $\mathrm{rMBP}_{\mathrm{G}}$ for $30 \mathrm{~min}$ at $37^{\circ} \mathrm{C}$. Neutrophils $\left(10^{6}\right.$ in 1 $\mathrm{ml}$ ) were then incubated for $10 \mathrm{~min}$ at $37^{\circ} \mathrm{C}$ with aliquots of these viral samples (final concentrations of Texas 77, Mem $71_{\mathrm{H}^{-}}-\mathrm{Bel}_{\mathrm{N}}$, Mem $71_{\mathrm{H}}-\mathrm{Bel} \mathrm{l}_{\mathrm{N}} / \mathrm{BS}$, and PR-8 were, respectively, 384, 192, 192, and $320 \mathrm{HAU} / \mathrm{ml})$, followed by addition of cytochalasin-B $(5 \mu \mathrm{g} / \mathrm{ml})$ and FMLP $\left(10^{-7} \mathrm{M} /\right.$ liter $)$ and measurement of $\mathrm{O}_{2}^{-}$production. The final concentrations of MBP in the neutrophil suspension are those indicated. Results represent mean \pm SEM ( $n=6$ experiments, except for the $6.6 \mu \mathrm{g} / \mathrm{ml}$ concentration of MBP where $n=3$ ) of FMLP-stimulated $\mathrm{O}_{2}^{-}$production in IAV-treated divided by control cells (i.e., percent of control). $\mathrm{No} \mathrm{O}_{2}^{-}$production was seen in response to opsonized or unopsonized IAV alone.

${ }^{*} P<0.05$ comparing FMLP-stimulated $\mathrm{O}_{2}^{-}$production in virustreated to control cells.

${ }^{\ddagger} P<0.05$ comparing FMLP-stimulated $\mathrm{O}_{2}^{-}$production rates in neutrophils treated with virus alone vs. virus opsonized with MBP.

Mem $71_{\mathrm{H}}-\mathrm{Bel}_{\mathrm{N}} / \mathrm{BS}$, or PR-8 viruses caused significant deactivation of FMLP-stimulated $\mathrm{O}_{2}^{-}$responses. Treatment of neutrophils with the same amount of Texas 77 IAV opsonized with 4.4 or $6.6 \mu \mathrm{g} / \mathrm{ml}$ of $\mathrm{rMBP}_{\mathrm{G}}$ caused significantly less deactivation than did unopsonized Texas 77 . Opsonization with 1.76 or $4.4 \mu \mathrm{g} / \mathrm{ml}$ of $\mathrm{rMBP}_{\mathrm{G}}$ reduced deactivation caused by $\mathrm{Mem} 71_{\mathrm{H}^{-}}$ $\mathrm{Bel}_{\mathrm{N}}$ significantly. Of note, no such protective effect was observed with respect to the Mem $71_{\mathrm{H}^{-}}-\mathrm{Bel}_{\mathrm{N}} / \mathrm{BS}$ mutant or PR-8 strains, indicating that binding to carbohydrate attachments near the globular end of the HA is necessary for MBP to inhibit deactivation.

The concentrations of $\mathrm{rMBP}_{\mathrm{G}}$ necessary to protect from deactivation were those that caused substantial inhibition of HA activity of the virus. The HA titers of Texas 77 and Mem $71_{\mathrm{H}}-\mathrm{Bel}_{\mathrm{N}}$ samples opsonized with $4.4 \mu \mathrm{g} / \mathrm{ml}$ of $\mathrm{rMBP}_{\mathrm{G}}$ were reduced, respectively, by 98 and $93 \%$ compared with un- opsonized controls. Enhancement of neutrophil $\mathrm{H}_{2} \mathrm{O}_{2}$ production in response to IAV could be demonstrated at lower concentrations than those that were necessary to protect from deactivation (Fig. 2). Note also that neither IAV nor MBP-opsonized IAV caused superoxide production in their own right. This is in accord with our previous findings using IAV (18, $19)$. It is unlikely, therefore, that the ability of MBP to protect neutrophils from the deactivating effects of IAV is a direct result of its ability to enhance respiratory burst responses to the virus itself.

\section{Effects of $r M B P_{D}$ on $I A V$ and on the IAV-neutrophil interaction}

Human serum MBP exists in two allelic forms that differ as a result of a single base pair change at base pair 230 that results in a Gly to Asp substitution. The latter form is less prevalent and is referred to as $\mathrm{rMBP}_{\mathrm{D}}$. It has been suggested (15) that this allelic form may be associated with susceptibility to infection. We therefore performed experiments to determine whether $\mathrm{rMBP}_{\mathrm{D}}$ differed from $\mathrm{rMBP}_{\mathrm{G}}$ in its interaction with IAV or neutrophils.

rMBP $_{D}$ had similar effects to rMBP $_{G}$ on IAV HA titers, inhibiting HA activity of the Texas 77 and $\mathrm{Mem} 71_{\mathrm{H}}-\mathrm{Bel}_{\mathrm{N}}$ strains of IAV while having no significant effect against the Mem $71_{\mathrm{H}}-\mathrm{Bel}_{\mathrm{N}} / \mathrm{BS}$ mutant strain. Fig. 3 depicts the dose-response relationship for HA inhibition of the Texas 77 strain of IAV resulting from preincubation with $\mathrm{rMBP}_{\mathrm{D}}$. Note that inclusion of $5 \mathrm{mM}$ EGTA during the incubation of the virus with $\mathrm{rMBP}_{\mathrm{D}}$ substantially inhibited the effects of the lectin on viral $\mathrm{HA}$ activity. Preincubation of concentrated $\mathrm{Mem} 71_{\mathrm{H}}-\mathrm{Bel}_{\mathrm{N}}$ IAV $(2,000 \mathrm{HAU} / \mathrm{ml})$ with 250,66 , and $33 \mu \mathrm{g} / \mathrm{ml}$ of $\mathrm{rMBP}_{\mathrm{D}}$ caused, respectively, $90 \pm 10,70 \pm 10$, and $50 \pm 0 \%$ (mean of two determinations) reductions in the HA titers whereas $100 \mu \mathrm{g} /$ $\mathrm{ml}$ of $\mathrm{rMBP}_{\mathrm{D}}$ had no effect on HA titers of 2,000 HAU of the $\operatorname{Mem} 71_{\mathrm{H}}-\mathrm{Bel}_{\mathrm{N}} / \mathrm{BS}$ strain. Inhibition of infectivity of Texas 77 was also found with $\mathrm{rMBP}_{\mathrm{D}}$ (PFU reduced from $7 \times 10^{9}$ to 6 $\times 10^{8}$ PFU.ml by preincubation with $\left.88 \mu \mathrm{g} / \mathrm{ml} \mathrm{rMBP}_{\mathrm{D}}\right)$.

As was the case with $\mathrm{rMBP}_{\mathrm{G}}$, significant enhancement of IAV-induced neutrophil $\mathrm{H}_{2} \mathrm{O}_{2}$ production was also observed when Texas 77 or $\mathrm{Mem} 7 \mathrm{1}_{\mathrm{H}}-\mathrm{Bel}_{\mathrm{N}}$ IAV were opsonized with rMBP $_{D}$. As shown in Fig. 4, significantly enhanced $\mathrm{H}_{2} \mathrm{O}_{2}$ responses were obtained with Texas 77 IAV opsonized with 1.1, 2.75 , or $5.5 \mu \mathrm{g} / \mathrm{ml}$ of this MBP preparation. For $\mathrm{Mem} 71_{\mathrm{H}^{-}}$ $\mathrm{Bel}_{\mathrm{N}}$, opsonization with $3.3 \mu \mathrm{g} / \mathrm{ml}$ of $\mathrm{rMBP}_{\mathrm{D}}$ increased $\mathrm{H}_{2} \mathrm{O}_{2}$ production from $0.98 \pm 0.18$ to $2.7 \pm 0.11 \mathrm{nmol} / \mathrm{min}$ per 4

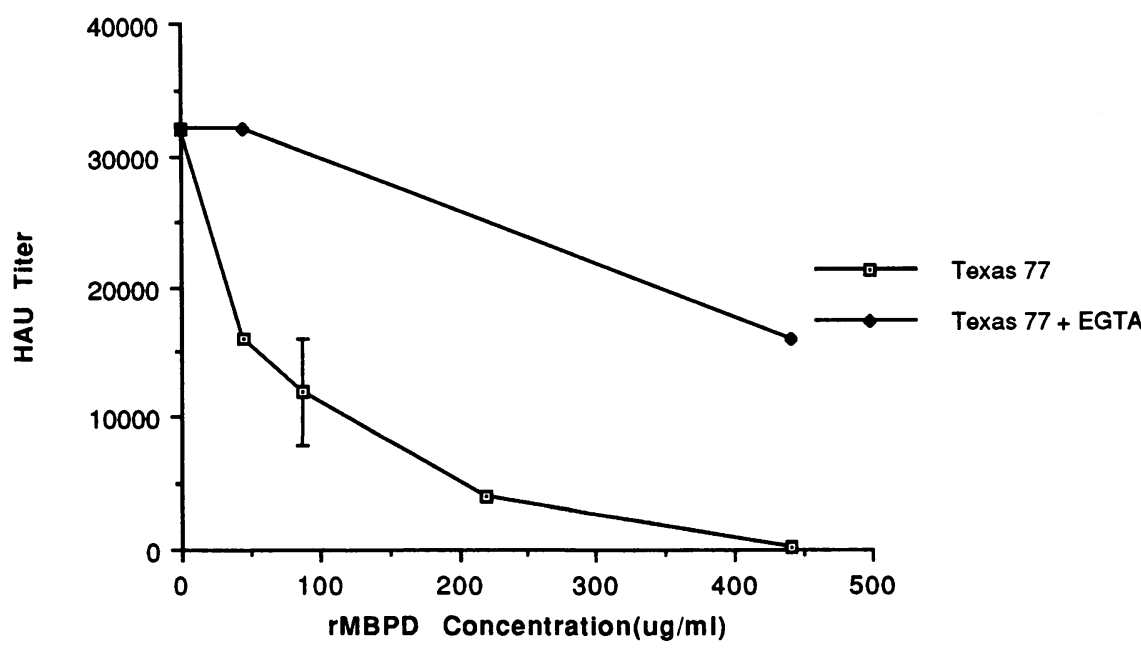

Figure 3. Effects of preincubation of concentrated Texas 77 IAV with rMBP $_{D}$ on HA titers. Experiments were performed as described in Fig. 1. These results represent mean \pm SEM of three experiments. Where error bars are not shown identical results were obtained in replicate experiments. Where indicated, $5 \mathrm{mM}$ EGTA was included during the incubation of MBP with IAV ( mean \pm SEM of two experiments). All MBP-treated samples (except those where EGTA was used) had significantly $(P<0.05)$ reduced HAU titers compared with untreated virus. 
$\times 10^{6}$ cells $(n=3 ; P<0.02)$. In parallel experiments no effect of $\mathrm{rMBP}_{\mathrm{D}}$ was found on $\mathrm{H}_{2} \mathrm{O}_{2}$ responses to the glycosylation mutant $\mathrm{Mem} 71_{\mathrm{H}^{-}}-\mathrm{Bel}_{\mathrm{N}} / \mathrm{BS}$ (control response $1.04 \pm 0.19$ vs. $0.42 \pm 0.04$ for MBP-treated samples). (Responses were higher in the experiments involving the effects of $\mathrm{rMBP}_{\mathrm{D}}$ on $\mathrm{H}_{2} \mathrm{O}_{2}$ production elicited by the Mem71 strains than in earlier experiments due to use of cytochalasin-B before virus).

As described above for $\mathrm{rMBP}_{\mathrm{G}}$, opsonization with $\mathrm{rMBP}_{\mathrm{D}}$ enhanced neutrophil membrane depolarization responses to Texas $77 \mathrm{IAV}$, an effect again inhibited by preincubation of the MBP with mannan (see Fig. 5).

Preincubation of Texas 77 IAV with rMBP $_{D}$ also significantly inhibited neutrophil deactivation caused by this virus strain. The $\mathrm{O}_{2}^{-}$response to FMLP was $77 \pm 3 \%$ of control when neutrophils were preincubated with $100 \mathrm{HAU} / \mathrm{ml}$ of Texas 77 IAV and $97 \pm 3 \%$ of control when neutrophils were pretreated with this amount of virus opsonized with a $1.1 \mu \mathrm{g} / \mathrm{ml}$ concentration of $\mathrm{rMBP}_{\mathrm{D}}(n=4 ; P<0.03)$. It thus appears that both forms of MBP have comparable functional activity as determined by these assay systems.

\section{Discussion}

In this report we demonstrate that two allelic variants of recombinant MBP inhibit HA activity of several $\mathrm{H} 3$ strains of IAV. Binding to a specific high mannose attachment present near the sialic acid-binding pocket of the HA of H3 IAV strains is crucial to these effects, as demonstrated using the glycosylation mutant of Mem $71_{\mathrm{H}}-\mathrm{Bel}_{\mathrm{N}}$ IAV. Opsonization of IAV with both forms of MBP also enhances neutrophil respiratory burst and membrane depolarization responses to cell-free IAV. Of further interest, the MBPs appear to protect neutrophils from the deactivating effects of IAV. This protective effect occurs at somewhat higher concentrations of MBP than are necessary to provide significant enhancement of the respiratory burst. Protection from deactivation requires substantial inhibition of viral HA activity. This finding is similar to results we have obtained using antibodies that neutralize IAV HA activity (unpublished data) and supports the concept that viral HA bind-

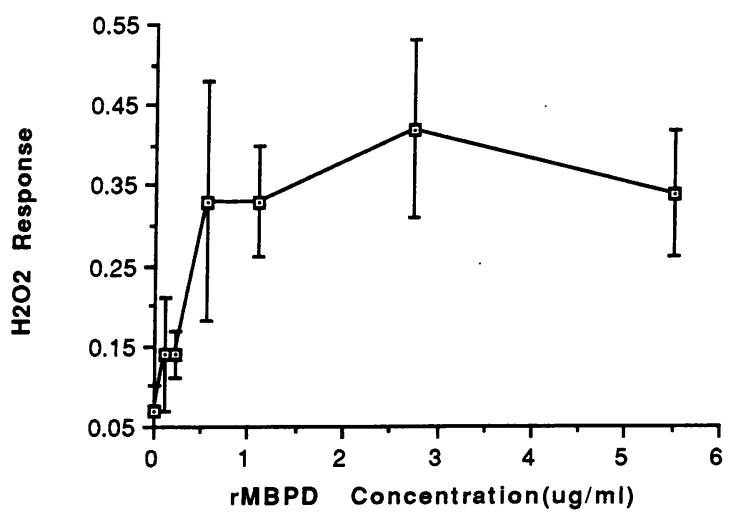

Figure 4. Concentration dependence of $\mathrm{rMBP}_{\mathrm{D}}$-induced enhancement of neutrophil $\mathrm{H}_{2} \mathrm{O}_{2}$ response to Texas 77 IAV. Experiments were performed as described in Fig. 2. $\mathrm{H}_{2} \mathrm{O}_{2}$ responses elicited in human neutrophils by unopsonized Texas 77 IAV $(480 \mathrm{HAU} / \mathrm{ml})$ or the same amount of Texas 77 IAV opsonized with the indicated concentrations of $\mathrm{rMBP}_{\mathrm{D}}$ are presented. For all concentrations of MBP (except $0.55 \mu \mathrm{g} / \mathrm{ml}$ where $n=2$ ) results represent mean \pm SEM of three to four experiments. Samples opsonized with 1.1, 2.75, and 5.5 $\mu \mathrm{g} / \mathrm{ml}$ of $\mathrm{rMBP}_{\mathrm{D}}$ caused significantly greater $(P<0.05)$ response than unopsonized IAV.

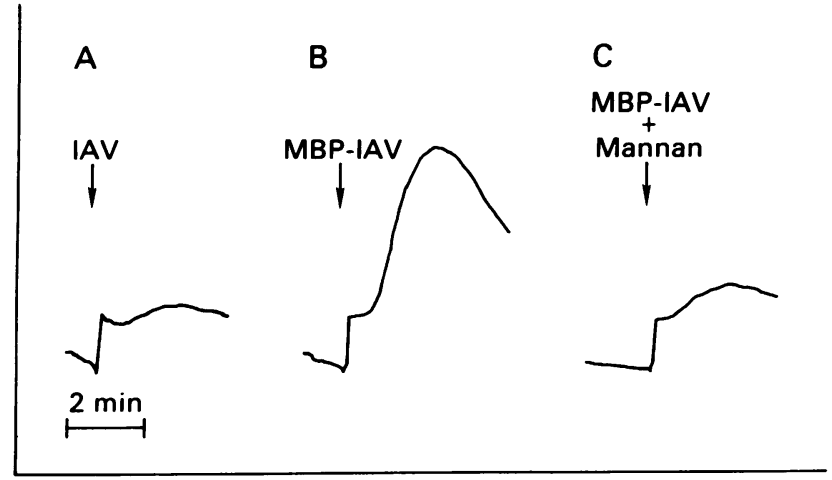

Figure 5. Representative tracing of neutrophil membrane depolarization response to $(A)$ Texas 77 IAV, $(B)$ Texas 77 IAV opsonized with $1.1 \mu \mathrm{g} / \mathrm{ml} \mathrm{rMBP}$, or $(C)$ Texas 77 with the same concentration of $\mathrm{rMBP}_{\mathrm{D}}$, which had been preincubated with $10 \mathrm{mg} / \mathrm{ml}$ mannan before addition of IAV. The final concentration of mannan upon incubation with neutrophils was $250 \mu \mathrm{g} / \mathrm{ml}$. These tracings are representative of four similar experiments using $\mathrm{rMBP}_{D}$ and of four experiments (described in text) using $\mathrm{rMBP}_{\mathrm{G}}$. For both $\mathrm{rMBP}_{\mathrm{D}}$ and $\mathrm{rMBP}_{\mathrm{G}}$, the rate of membrane depolarization was significantly ( $P$ $<0.03$ ) increased by opsonization with MBP. Where mannan was included no MBP-related enhancement was seen. Mannan alone at the same final concentration did not alter responses elicited by IAV or FMLP in this assay (text and data not shown).

ing to neutrophil surface sialic acid residues is critical for causing deactivation. This corroborates the finding of Cassidy et al. (25) that purified IAV HA preparations can mediate deactivation. It is of further interest that, in the setting where deactivation and HA activity are strongly inhibited by MBP, the opsonized virus still activates more vigorous neutrophil respiratory burst responses than unopsonized controls. Whether MBP-opsonized IAV activates neutrophils in a qualitatively different manner than the unopsonized virus requires further study. Activation by MBP-opsonized IAV is similar to that triggered by the unopsonized virus in that only $\mathrm{H}_{2} \mathrm{O}_{2}$, without accompanying superoxide, is produced. We have studied this phenomenon extensively with respect to unopsonized $\operatorname{IAV}(18,19,26)$. Our findings indicate that the lack of superoxide production may be accounted for by postulating that the virus-induced respiratory burst occurs largely at an intracellular site from which $\mathrm{H}_{2} \mathrm{O}_{2}$, but not $\mathrm{O}_{2}^{-}$, can diffuse out to the extra-cellular space and be detected (19). This may also be the case for the burst elicited by MBP-opsonized IAV, although this has yet to be proven.

We have conducted experiments with MBP isolated from human serum (gift of Dr. Jens Jensenius, University of Aarhus, Aarhus, Denmark) and found HA inhibition, enhancement of neutrophil respiratory burst responses, and inhibition of IAVinduced neutrophil deactivation with this preparation as well (data not shown). We have also observed similar effects using bovine conglutinin (Hartshorn, K. L., K. Sastry, M. R. White, D. Brown, T. Okarma, Y. M. Lee, and A. I. Tauber, manuscript submitted for publication). There are extensive similarities between MBP and conglutinin in terms of lectin activity and macromolecular structure $(6,7)$. Both molecules also have the ability to bind to the cellular C1q receptor via their highly conserved collagen domains (27). Recent studies indicate that conglutinin may be the major constituent of the bovine serum beta inhibitor of IAV infectivity whereas another lectin, possibly MBP, plays this role in murine serum (5). The 
finding that these lectins also favorably alter neutrophil interactions with IAV adds an important new dimension to our understanding of their potential role in ante-antibody immunity to this virus. It may be that the related lectins found in pulmonary surfactant (6) have similar effects vis-a-vis IAV as well. These surfactant lectins may be particularly well positioned to contribute to the initial defense against IAV in the lung.

The various effects of $\mathrm{rMBP}_{\mathrm{G}}$ in our experiments were observed at concentrations of the lectin normally present in human serum (14). All of the observed effects would be expected to influence favorably the outcome of IAV infection in vivo, either through direct antiviral effects of the lectin or through enhancing neutrophil antimicrobial mechanisms and protecting the neutrophil from virus-induced dysfunction. The effective concentrations of $\mathrm{rMBP}_{\mathrm{G}}$ and $\mathrm{rMBP}_{\mathrm{D}}$ appear to be very similar from our data. In experiments using the two preparations of MBP to opsonize bacteria (14), major differences in ability to bind to or opsonize bacteria were not found. It appears likely, therefore, that the ability to opsonize organisms is not dramatically different between the two allelic variants of MBP. However, $\mathrm{MBP}_{\mathrm{G}}$ was able to fix complement via the classical pathway, whereas $\mathrm{rMBP}_{\mathrm{D}}$ was not, despite the fact that both recombinant preparations were capable of forming hexamers (i.e., $\mathrm{Cl}_{\mathrm{q}}$-like configurations). The precise role of mannose-binding protein in IAV infection in vivo remains to be determined. One intriguing possibility that one can conclude from our in vitro studies is that absent or dysfunctional MBP may contribute to bacterial superinfection as a result of neutrophil deactivation. In this regard it would be interesting to identify patients who had bacterial superinfection after IAV infection and to determine the concentrations of MBP in their serum and respiratory secretions.

Further studies are still required on how mannose-binding proteins alter IAV binding, uptake into and survival in phagocytes. The relative contribution of putative IAV and MBP receptors on the neutrophil to activation needs to be established. Addition of complement to the MBP-opsonized virus model is likely to result in more potent neutrophil activation and viral killing. Studies of the interaction of MBP (or conglutinin) with other respiratory viral strains may reveal expanded clinical relevance of the lectins in preimmune antiviral responses. Specifically, $\mathrm{H} 1 \mathrm{IAV}$ isolates other than PR-8 may interact with MBP. The WSN strain has more mannose residues on its HA than PR-8 (28), and more recently isolated H1 strains (since the reintroduction of this subtype into active circulation in the human population in 1976) have acquired changes in oligosaccharide attachments as compared with PR-8 (29) and are sensitive to beta-inhibitors (5). The effects of MBP on influenza B and parainfluenza viruses are also of interest. We believe that the results of these various studies will confirm an important role for mammalian C-type lectins, in conjunction with phagocytic cells, in the natural immune response to influenza and perhaps other related virus infections.

\section{Acknowledgments}

We thank Ann Marie Happnie for her expert secretarial assistance in the preparation of this manuscript.

This study was supported by National Institutes of Health grants: AI-29550-03 (K. L. Hartshorn), HL-335565-08 (A. I. Tauber), and a Grant-in-Aid from the Bristol Myers Medical Foundation (R. A. B. Ezekowitz). R. A. B. Ezekowitz is an established investigator of the American Heart Association.

\section{References}

1. Couch, R. B., and J. A. Kasel. 1983. Immunity to influenza in man. Annu. Rev. Microbiol. 37:529-549.

2. Wiley, D. C. 1987. The structure and function of the hemagglutinin membrane glycoprotein of influenza virus. Annu. Rev. Biochem. 56:365-394.

3. Kilbourne, E. D. 1987. Animal influenza In Influenza. Plenum Med. Book Co., New York.

4. Anders, E. M., C. A. Hartley, and D. C. Jackson. 1990. Bovine and mouse serum beta inhibitors of the influenza $A$ viruses are mannose-binding lectins. Proc. Natl. Acad. Sci. USA. 87:4485-4489.

5. Hartley, C. A., D. C. Jackson, and M. E. Anders. 1992. Two distinct serum mannose-binding lectins function as beta inhibitors of influenza virus: identification of bovine serum inhibitor as conglutinin. J. Virol. 66:4358-4363.

6. Thiel, S., and K. B. M. Reid. 1989. Structures and functions associated with the group of mammalian lectins containing collagen-like sequences. FEBS (Fed. Eur. Biochem. Soc.) Lett. 250:78-84.

7. Drickamer, K. 1988. Two distinct classes of carbohydrate-recognition domains in animal lectins. J. Biol. Chem. 263:94937-94947.

8. Ezekowitz, R. A. B. 1991. Ante-antibody immunity. In Current Biology. P. Newmark, editor. London. 60-62.

9. Ezekowitz, R. A. B., L. E. Day, and G. A. Herman. 1988. A human mannose-binding protein is an acute phase reactant that shares sequence homology with other vertebrate lectins. J. Exp. Med. 167:1034-1046.

10. Sastry, K., K. Zahedi, J. Lelias, A. S. Whitehead, and R. A. B. Ezekowitz. 1991. Molecular Characterization of the mouse mannose-binding proteins. $J$. Immunol. 147:692-697.

11. Kuhlman, M., K. Joiner, and R. A. B. Ezekowitz. 1989. The human mannose-binding protein functions as an opsonin. J. Exp. Med. 169:1733-1745.

12. Super, M., R. J. Levinsky, and M. W. Turner. 1990. The level of mannanbinding protein regulates the binding of complement-derived opsonins to mannan and zymosan at low serum concentrations. Clin. Exp. Immunol. 79:144-150.

13. Ezekowitz, R. A. B., M. Kuhlman, J. E. Groopman, and R. A. Byrn. 1989. A human serum mannose-binding proteins inhibits in vitro infection by the human immunodeficiency virus. J. Exp. Med. 169:185-196.

14. Super, M., S. D. Gillies, S. Foley, K. Sastry, J. E. Schweinle, V. A. Silverman, and R. A. B. Ezekowitz. 1992. Distinct and overlapping functions of allelic forms of human mannose-binding protein. Nature Genetics. 2:50-55.

15. Sumiya, M., M. Super, P. Tabona, R. J. Levinsky, T. Arai, M. W. Turner, and J. A. Summerfield. 1991. Molecular basis of opsonic defect in immunodeficient children. Lancet. 337:1569-1570.

16. Hartshorn, K. L., A. B. Karnad, and A. I. Tauber. 1990. Influenza A virus and the neutrophil: a model of natural immunity. J. Leukocyte Biol. 47:176.

17. Hartshorn, K. L., D. Daigneault, and A. I. Tauber. 1992. Phagocyte responses to viral infection. In Inflammation: Basic Principles and Clinical Correlates. J. I. Gallin, I. M. Goldstein, and R. Snyderman, editors. 2nd ed. Raven Press, New York. 1017-1031.

18. Hartshorn, K. L., M. Collamer, M. R. White, J. H. Schwartz, and A. I. Tauber. 1990. Characterization of influenza A virus activation of the human neutrophil. Blood. 75:218-226.

19. Hartshorn, K. L., D. E. Daigneault, M. R. White, M. Tuvin, J. L. Tauber, and A. I. Tauber. 1992. Comparison of influenza A virus and formyl-methionylleucyl-alanine activation of the human neutrophil. Blood. 79:1049-1057.

20. Ratcliffe, D. R., S. L. Nolin, and E. B. Cramer. 1988. Neutrophil interaction with influenza infected epithelial cells. Blood. 72:142-149.

21. Hartshorn, K. L., M. Collamer, M. Auerbach, J. B. Myers, N. Pavlotsky, and A. I. Tauber. 1988. Effects of influenza A virus on human neutrophil calcium metabolism. J. Immunol. 141:1295.

22. Hartshorn, K. L., and A. I. Tauber. 1988. The influenza virus-infected phagocyte. A model of deactivation. Hemat. Oncol. Clin. North Am. 2:301-315.

23. Caton, A. J., G. G. Brownlee, J. W. Yewdell, and W. Gerhard. 1982. The antigenic structure of the influenza virus $A / P R / 8 / 34$ hemagglutinin (H1 subtype). Cell. 31:417-427.

24. Schwarz, R. T., and H-D Klenk. 1981. Carbohydrates of influenza virus. IV. Strain-dependent variations. Virology. 113:584-593.

25. Cassidy, L. F., D. S. Lyles, and J. A. Abramson. 1989. Depression of polymorphonuclear leukocyte functions by purified influenza virus hemagglutinin and sialic acid binding lectins. J. Immunol. 142:4401-4406.

26. Hartshorn, K. L., D. E. Daigneault, M. R. White, and A. I. Tauber. 1992. Anomalous features of human neutrophil activation by influenza $\mathrm{A}$ virus are shared by related viruses and sialic acid-binding lectins. J. Leukocyte Biol. 51:230-236.

27. Malhotra, R., S. Thiel, K. B. M. Reid, and R. B. Sim. 1990. Human leukocytes $\mathrm{Cl}_{\mathrm{a}}$ receptor binds other soluble proteins with collagen domains. $J$. Exp. Med. 172:955-959.

28. Nakamura, K., and R. W. Compans. 1979. Host cell- and virus strain-dependent differences in oligosaccharides of hemagglutinin glycoproteins of influenza A viruses. Virology. 95:8-23.

29. Raymond, F. L., A. J. Caton, N. J. Cox, A. P. Kendal, and G. G. Brownlee. 1983. Anigenicity and evolution amongst recent influenza viruses of the HIN1 subtype. Nucl. Acids Res. 11:7191-7203. 